\title{
Environmental change within the Balkan region during the past ca. 50 ka recorded in the sediments from lakes Prespa and Ohrid
}

\author{
B. Wagner ${ }^{1}$, H. Vogel ${ }^{1}$, G. Zanchetta ${ }^{2}$, and R. Sulpizio ${ }^{3}$ \\ ${ }^{1}$ Institute for Geology and Mineralogy, University of Cologne, Köln, Germany \\ ${ }^{2}$ Dipartimento di Scienze della Terra, INGV sez. Pisa, IGG-CNR, Pisa, Italy \\ ${ }^{3}$ CIRISIVU, c/o Dipartimento Geomineralogico, Bari, Italy
}

Received: 3 May 2010 - Published in Biogeosciences Discuss.: 10 May 2010

Revised: 1 October 2010 - Accepted: 8 October 2010 - Published: 19 October 2010

\begin{abstract}
Lakes Prespa and Ohrid, in the Balkan region, are considered to be amongst the oldest lakes in Europe. Both lakes are hydraulically connected via karst aquifers. From Lake Ohrid, several sediment cores up to $15 \mathrm{~m}$ long have been studied over the last few years. Here, we document the first long sediment record from nearby Lake Prespa to clarify the influence of Lake Prespa on Lake Ohrid and the environmental history of the region. Radiocarbon dating and dated tephra layers provide robust age control and indicate that the $10.5 \mathrm{~m}$ long sediment record from Lake Prespa reaches back to $48 \mathrm{ka}$. Glacial sedimentation is characterized by low organic matter content and absence of carbonates in the sediments, which indicate oligotrophic conditions in both lakes. Holocene sedimentation is characterized by particularly high carbonate content in Lake Ohrid and by particularly high organic matter content in Lake Prespa, which indicates a shift towards more mesotrophic conditions in the latter. Long-term environmental change and short-term events, such as related to the Heinrich events during the Pleistocene or the $8.2 \mathrm{ka}$ cooling event during the Holocene, are well recorded in both lakes, but are only evident in certain proxies. The comparison of the sediment cores from both lakes indicates that environmental change affects particularly the trophic state of Lake Prespa due to its lower volume and water depth.
\end{abstract}

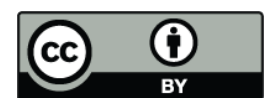

Correspondence to: B. Wagner (wagnerb@uni-koeln.de)

\section{Introduction}

Lakes Prespa and Ohrid on the Balkan Peninsula form a hydraulic system, which is considered to have formed during the early to mid Pliocene, roughly two to five million years ago (Stankovic, 1960; Meybeck, 1995). Both lakes are presumed to be among the oldest existing lakes in Europe. In the earliest stage of their existence, both lakes probably were part of a much bigger lake group called the Dessaretes (Stankovic, 1960), which also includes Lake Mikri Prespa (Greece, Albania) and Lake Maliq (Albania).

After its formation or separation from the other lakes, Lake Ohrid is supposed to have existed continuously and thus could be the oldest European lake (Salemaa, 1994; see also Albrecht and Wilke, 2008). Lake Prespa, in contrast, is much shallower and thus has probably been more susceptible to complete desiccation at various times in the past. Their differing geological histories might explain differences in extant faunas despite their hydrological connection via karst aquifers (see also Wilke et al., 2010). Lake Ohrid is famous for its more than 200 endemic species. Though, total number of endemic species is higher in lakes Baikal, Tanganyika, Victoria and Malawi, Lake Ohrid is much smaller than these lakes and, considering surface area, is probably by far the most diverse lake in the world for its size (Albrecht and Wilke, 2008). Lake Prespa is an important breeding site for rare water-bird species and also harbours endemic species, but there is little faunal exchange and overlap to the Lake Ohrid fauna (Albrecht and Wilke, 2008). The ecological importance of both lakes has been confirmed by the declaration of Lake Ohrid as an UNESCO world heritage site in 1979 and by the establishment of the Prespa National Park in 1999. Increasing population in both lake catchments, increasing

Published by Copernicus Publications on behalf of the European Geosciences Union. 
eutrophication of the lake waters, and ongoing use of lake water for agriculture jeopardize the ecosystems today. Relatively short sediment sequences from both lakes document their recent eutrophication and have been used to study the influence of water supply from the modern day mesotrophic Lake Prespa to the oligotrophic Lake Ohrid (Matzinger et al., 2006a, 2007).

Long sediment sequences have only been sparsely used to infer the regional environmental history. Such sequences recovered so far from Lake Ohrid indicate that this lake sensitively records short- and long-term climatic and environmental change over the last glacial/interglacial cycle (Roelofs and Kilham, 1983; Belmecheri et al., 2009; Wagner et al., 2009; Lézine et al., 2010; Vogel et al., 2010a). Moreover, the occurrence of tephras and cryptotephras in these sequences indicates that the lake is a valuable archive for ash dispersal originating from the explosive eruptions of Italian volcanoes during the Late Quaternary (Wagner et al., 2008; Vogel et al., 2010c, Sulpizio et al., 2010).

Comparable long sediment sequences from Lake Prespa have not been taken prior to this study. Here, we present a new sediment record from Lake Prespa, which allows a first characterization of the Late Quaternary sedimentation in this lake. A comparison with the sedimentary record from Lake Ohrid will (i) help to better understand the long-term interactions between Lake Prespa and Lake Ohrid, (ii) allow a better discrimination between local and regional environmental change and their driving forces, (iii) provide a better estimate of the impact of short-term climate events in the Balkan region, and (iv) provide more information about ash dispersal on the Balkan Peninsula.

\section{Study sites}

Lake Prespa is a transboundary lake shared between the Republics of Macedonia, Albania, and Greece (Fig. 1). The lake is located at $849 \mathrm{~m}$ above sea level (a.s.l.), has a surface area of $254 \mathrm{~km}^{2}$, a catchment area of $1300 \mathrm{~km}^{2}$, a maximum water depth of $48 \mathrm{~m}$, a mean water depth of $14 \mathrm{~m}$, and a volume of $3.6 \mathrm{~km}^{3}$. The total inflow is estimated to $16.9 \mathrm{~m}^{3} \mathrm{~s}^{-1}$, with $56 \%$ originating from river runoff from numerous small streams, $35 \%$ from direct precipitation, and 9\% from Lake Mikri Prespa to the south (Matzinger et al., 2006a). Lake Prespa has no surface outlet. Water loss derives through evaporation (52\%), irrigation (2\%) and outflow through karst aquifers $(46 \%)$. The hydraulic residence time in Lake Prespa is about 11 years. A significant lake level decrease of more than $7 \mathrm{~m}$ was measured between 1965 and 1996 (Popovska and Bonacci, 2007) and is mainly caused by irrigation and agriculture. An additional lowering of at least $1 \mathrm{~m}$ was observed during the last 9 years. As Lake Prespa is relatively shallow compared to its large surface area, windinduced mixing leads to a complete destratification of the water column from autumn to spring (Matzinger et al., 2006a).

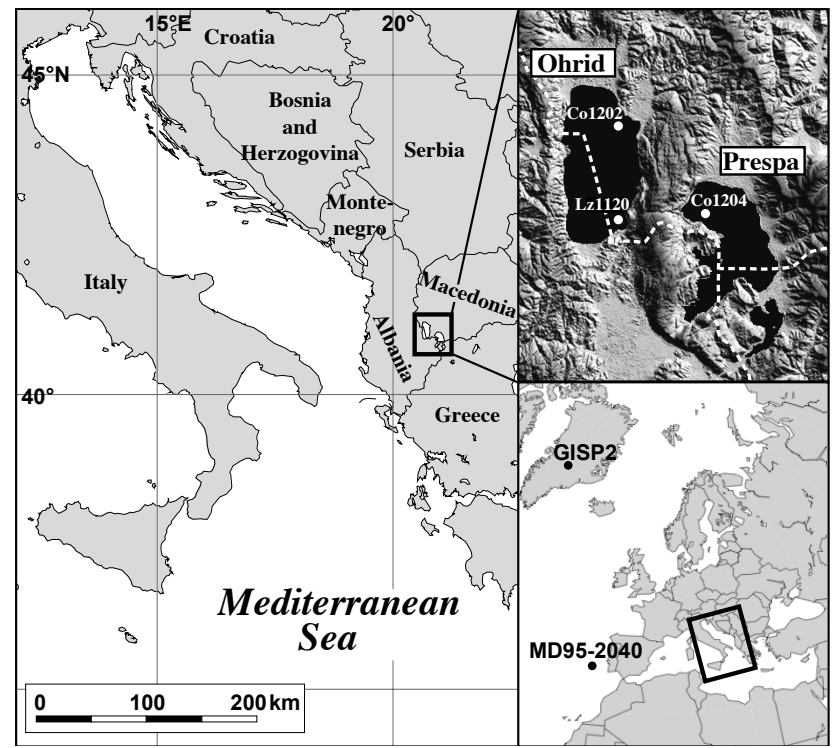

Fig. 1. Map of the northern Mediterranean region showing the location of lakes Ohrid and Prespa. White dots indicate coring locations Lz1120 and Co1202 in the southeastern and northeastern part of Lake Ohrid, and coring location Co1204 in the northwestern part of Lake Prespa. Dashed white line indicates the border between Albania, Macedonia and Greece. The insert at the right (bottom) shows the locations of the marine sediment core MD95-2040 from the western Iberian margin and the GISP2 ice core from Greenland.

Anoxic bottom waters in summer and an average concentration of $31 \mathrm{mg} \mathrm{m}^{-3}$ total phosphorus (TP) in the water column characterize the lake as mesotrophic today. However, short sediment cores and hydrological measurements indicate recent eutrophication (Matzinger et al., 2006a) and imply that Lake Prespa was more oligotrophic in the past.

Lake Ohrid is separated from Lake Prespa by the Galiçica mountain range (Fig. 1). Lake Ohrid is also a transboundary lake, shared by the Republics of Macedonia and Albania. The lake is located at $693 \mathrm{~m}$ a.s.l., has a surface area of $358 \mathrm{~km}^{2}$, a maximum water depth of $289 \mathrm{~m}$, a mean water depth of $155 \mathrm{~m}$, and a volume of $55.4 \mathrm{~km}^{3}$. The direct catchment area of Lake Ohrid measures $1310 \mathrm{~km}^{2}$, however, stable isotope measurements and tracer experiments revealed that Lake Ohrid is partly fed by karst aquifers from Lake Prespa (Anovski et al., 1980; Eftimi and Zoto, 1997), which increases the total catchment to $2610 \mathrm{~km}^{2}$. The total inflow of water can be estimated to $37.9 \mathrm{~m}^{3} \mathrm{~s}^{-1}$, with ca. $25 \%$ originating from direct precipitation and $25 \%$ from riverine inflow. About $50 \%$ of the total inflow derives from karst aquifers, of which ca. $8 \mathrm{~m}^{3} \mathrm{~s}^{-1}$ are believed to come from Lake Prespa (Matzinger et al., 2006b). Evaporation (40\%) and the main outflow, the river Crn Drim (60\%), balance the water budget of Lake Ohrid. The hydraulic residence time in Lake Ohrid is about 70 years. Total decrease of the average lake level between 1965 and 1996 was less than $1 \mathrm{~m}$ (Popovska 
and Bonacci, 2007), however, the water level has been artificially regulated since 1962 . Mixing of the upper 150 to $200 \mathrm{~m}$ of the water column of Lake Ohrid occurs every winter, and complete mixing of the lake occurs only every few years (Hadzisce, 1966; Matzinger et al., 2006b). The mixing is mainly induced by southerly or northerly winds, leading to an anticlockwise current, so-called Ekman pumping and upwelling of relatively cold waters mainly in the central northern part of the lake (Stankovic, 1960; Matzinger et al., 2006b; Vogel et al., 2010b). Despite the irregular mixing, moderate oxygen saturation in the bottom waters and an average TP concentration of $4.5 \mathrm{mg} \mathrm{m}^{-3}$ (Matzinger et al., 2006a) characterize the lake as oligotrophic.

\section{Material and methods}

An $8.85 \mathrm{~m}$ long sediment record was recovered from the central northern part of Lake Ohrid in 1973 (Roehlofs and Kilham, 1983). Two cores measuring about $10 \mathrm{~m}$ in length were recovered in 2004 and 2005 from the southwestern (Belmecheri et al., 2009) and the southeastern (Wagner et al., 2009) part of the lake (Fig. 1) using a floating platform, and gravity and piston corers (UWITEC Co. Austria). The longest and best-dated record so far existing is core Co1202 from the northeastern part of the lake (Vogel et al., 2010a). This core is $15 \mathrm{~m}$ long and dates back to $136 \mathrm{ka}$ and hence will be mainly used for a comparison with the sediment record from Lake Prespa. The chronology of core Co1202 is well constrained by radiocarbon dating and the occurrence of 10 tephra and cryptotephra layers (Vogel et al., 2010c).

From Lake Prespa, a $10.5 \mathrm{~m}$ long sediment sequence was recovered in autumn 2007, also using a floating platform, and gravity and piston corers (UWITEC Co. Austria). The coring location (labelled site Co1204) is in the northwestern part of the lake (Fig. 1), where a hydroacoustic survey indicated a water depth of $14 \mathrm{~m}$ and undisturbed sedimentation. Correlation of individual sediment cores (to composite core Co1204) measuring up to $3 \mathrm{~m}$ in length, but taken during differing coring drives, was accomplished using field measurements, macroscopic core description and physical and geochemical properties of the sediments.

The analytical work on core Co1204 was based on the same methods as applied to core Co1202 from the northeastern part of Lake Ohrid (see Vogel et al., 2010a, for details). The analytical work focused on high-resolution X-ray fluorescence (XRF) measurements, geochemical measurements, and the determination of the grain-size distribution. XRF scanning was carried out at a resolution of $0.5 \mathrm{~mm}$ and an analysis time of $20 \mathrm{~s}$ per measurement using an ITRAX core scanner (COX Ltd., Sweden). The obtained count rates (here for $\mathrm{Ca}, \mathrm{K}, \mathrm{Ti}, \mathrm{Sr}, \mathrm{Zr}$, and $\mathrm{Mn}$ ) were smoothed using a 5-pt running mean. Geochemical measurements were performed in $2 \mathrm{~cm}$ intervals on freeze-dried and homogenized subsamples. Concentrations of total carbon (TC), total nitrogen
(TN), and total sulphur (TS) were measured with a MICRO CUBE elemental analyzer (VARIO Co.). Total organic carbon (TOC) was quantified from the difference between total carbon (TC) and total inorganic carbon (TIC), which were measured with a DIMATOC 200 (DIMATEC Co.). Grainsize analyses were carried out in intervals of between 4 and $8 \mathrm{~cm}$ on clastic detritus after removal of calcium carbonate, finely dispersed iron sulphides, and biogenic silica. The grain-size distribution was measured using a Micromeritics Saturn Digisizer 5200 laser particle analyzer and calculated from the average values of 3 runs. The grain-size distribution was then separated in a fine fraction $(<20 \mu \mathrm{m})$ and a coarse fraction $(>20 \mu \mathrm{m})$ for a simplified graphical presentation.

The chronology of core Co1204 is based on radiocarbon dating (Table 1) and tephrochronology (Table 2). Radiocarbon dating was performed on macrofossil remains from 15 horizons. Reliable radiocarbon ages were calibrated into calendar years before present (cal. yr BP) using CalPal2007 online and the Cal-Pal2007_HULU calibration curve (Danzeglocke et al., 2008). Three tephra layers at depths of 879.3-863.3 cm (PT0704-3), 767.2-764.2 cm (PT07042), and 672.5-667.5 cm (PT0704-1) were identified throughout the core (Sulpizio et al., 2010) and additionally used to establish an age-depth model for core Co1204. As for core Co1202 from Lake Ohrid (cf. Vogel et al., 2010c), the agedepth model for core Co1204 is based on the assumption that the sediment surface represents the year of the coring campaign (2007) and on a linear interpolation between the dated horizons after removal of the tephra layers. Offsets in age assignments between lakes Prespa and Ohrid could be due to the material used for radiocarbon dating. In Lake Prespa, only macrofossil remains were taken for radiocarbon dating. In Lake Ohrid, bulk organic carbon was partly used, which is known to include hard water, reservoir or contamination effects of up to ca. 1500 years (Wagner et al., 2008; Vogel et al., 2010c).

\section{Results and discussion}

Core Co1204 from Lake Prespa is mainly composed of two lithological units (Fig. 2). The lower unit reaches from the core base at $1050 \mathrm{~cm}$ to $314 \mathrm{~cm}$ depth and is characterized by its greyish colour and absence of lamination in the lower part of the core. Fine-grained clastic matter dominates the sediment composition and $\mathrm{K}$ and $\mathrm{Ti}$ counts are high. This grain-size composition, which indicates a low energy transport, suggests that there was no significant inflow into Lake Prespa close to the coring location. Sporadic occurrence of sand and gravel grains implies that the lake was ice covered at least during winter and that gravel and coarse sand were transported by ice floes during ice break up in spring. Similar observations have been made in glacial sediments from Lake Ohrid (Wagner et al., 2008; Vogel et al., 2010a). Carbonates 
Table 1. Radiocarbon age determinations from Lake Prespa core Co1204. The depth values in brackets of samples KIA36356-KIA36358 indicate depths after subtraction of tephra thicknesses.

\begin{tabular}{|c|c|c|c|c|c|c|c|}
\hline sample & core section & corr. depth $(\mathrm{cm})$ & material & $\mathrm{C}(\mathrm{mg})$ & ${ }^{13} \mathrm{C}(\%)$ & ${ }^{14} \mathrm{C}$ age $(\mathrm{yr} \mathrm{BP})$ & calendar age (cal. yr BP) \\
\hline ETH39603 & Co1204-1 & 9 & shell remain & & -7.30 & $-955 \pm 35$ & 1 \\
\hline ETH39604 & Co1204-3 & 43 & fish scale & & -34.70 & $1070 \pm 50$ & $1000 \pm 90$ \\
\hline KIA36347 & Co1204-1 & 53 & plant remains & 0.3 & -27.51 & $235 \pm 50$ & 2 \\
\hline ETH39605 & Co1204-3 & 96 & plant remains & & -26.70 & $3665 \pm 40$ & $3990 \pm 100$ \\
\hline KIA36348 & Co1204-3 & 119 & plant remains & 1.1 & -29.33 & $3745 \pm 30$ & $4090 \pm 60$ \\
\hline KIA36349 & Co1204-3 & $166-172$ & plant remains & 0.1 & -24.48 & $6135 \pm 480$ & 2 \\
\hline ETH39606 & Co1204-3 & 175 & plant remains & & -27.00 & $5265 \pm 40$ & $6055 \pm 125$ \\
\hline KIA36351 & Co1204-3 & 186 & plant remains & 0.1 & -23.71 & $6536 \pm 275$ & 2 \\
\hline KIA36352 & Co1204-3 & 216 & plant remains & 1.7 & -25.72 & $6230 \pm 40$ & $7140 \pm 85$ \\
\hline KIA36353 & Co1204-3 & 239 & plant remains & 1.9 & -27.80 & $6970 \pm 40$ & $7800 \pm 50$ \\
\hline KIA36354 & Co1204-4 & 308 & plant remains & 1.1 & -26.36 & $9075 \pm 55$ & $10250 \pm 50$ \\
\hline KIA36355 & Co1204-4 & 314 & fish remains & 0.2 & -21.47 & $10386 \pm 265$ & 2 \\
\hline KIA36356 & Co1204-6 & $829(821)$ & plant remains & 1.9 & -27.40 & $33270 \pm 540$ & $37990 \pm 1130$ \\
\hline KIA36357 & Co1204-7 & 887 (863) & plant remains & 3.3 & -27.01 & $37960 \pm 570$ & 3 \\
\hline KIA36358 & Co1204-7 & $1001(977)$ & plant remains & 2.0 & -27.14 & $>45680$ & 3 \\
\hline
\end{tabular}

${ }^{1}$ sample was not calibrated and used for age-depth model due to influence of bomb ${ }^{14} \mathrm{C}$.

2 samples were not calibrated and used for age-depth model due to very low $\mathrm{C}$ contents.

3 samples were not used for age-depth model as they are close to or above the limits of radiocarbon dating.

Table 2. Tephra horizons, depths, correlation with tephras from other records, and inferred ages in core Co1204 from Lake Prespa (for details see Sulpizio et al., 2010).

\begin{tabular}{llllll}
\hline sample & core section & corr. depth $(\mathrm{cm})$ & correlation & age (ka) & reference \\
\hline PT0704-1 & Co1204-5 & $672.5-667.5$ & Y-3 & $30670 \pm 0.230$ & Zanchetta et al., 2010 \\
PT0704-2 & Co1204-6 & $767.2-764.2$ & Codola & $34270 \pm 0.870$ & Vogel et al., 2010c \\
PT0704-3 & Co1204-6/7 & $879.3-863.3$ & Y-5 & $39280 \pm 0.110$ & De Vivo et al., 2001 \\
\hline
\end{tabular}

are absent throughout most of this lithological unit, as shown by low TIC content and negligible Ca counts. A few spikes in TIC do not correlate with the Ca suggesting that the carbonates are not calcite. The proportion of organic matter is very low and anti-correlates with the $\mathrm{K}$ and $\mathrm{Ti}$. The very low carbonate and organic matter implies a low productivity or high decomposition rate during deposition of this lithological unit. In the upper part of this unit, between ca. 600 and $314 \mathrm{~cm}$ depth, an increase in lamination occurs. The lamination is irregular and made up of individual dark greyish to black spots, which partly form distinct horizons. XRF shows that the visually dark grey to black horizons are characterized by peaks in Mn (Fig. 2) and hence suggest concretions formed along particular horizons. Concretionary $\mathrm{Mn}$ and $\mathrm{Fe}$ horizons have also been observed in the glacial Lake Ohrid sediments (Vogel et al., 2010a) and in Lake Baikal sediments (Granina et al., 2004) where they are thought to be related to either shifts in the redox conditions of the bottom waters or by significant change in the sedimentation regime. The dark horizons thus likely represent paleo redox fronts, which are partly preserved in the sediment. In a study of lake Baldeg- gersee in Switzerland, oxygen input by wind induced mixing is thought to explain the production of a particle flux of $\mathrm{MnO}_{2}$ to the sediment surface, which could be partially preserved in the sediment as $\mathrm{MnCO}_{3}$ (Schaller et al., 1997). A similar process with changing redox conditions could have occurred in Lake Prespa and would explain the correlation between Mn and TIC and the absence of corresponding Ca peaks.

Coarser sediments, significantly increased $\mathrm{Sr}$ values, and a distinct maximum in $\mathrm{Zr}$ define the occurrence of three tephra horizons in the lower lithological unit (Fig. 2, Table 2). The geochemical composition of the tephras and their correlation to known eruptions is discussed in detail in Sulpizio et al. (2010). Tephra PT0704-3 between 879.3-863.3 cm depth corresponds with the Y-5 tephra. Tephra PT0704-02 occurs between $767.2-764.2 \mathrm{~cm}$ depth and can tentatively be correlated with the Codola tephra. Tephra PT0704-01 between $672.5-667.5 \mathrm{~cm}$ depth correlates with the Y-3 tephra (Fig. 2). The tephrochronological ages are supported by radiocarbon ages from this unit. Sample KIA36356 from $829 \mathrm{~cm}$ depth provides an age of $37990 \mathrm{cal}$. yr BP, which matches well with 


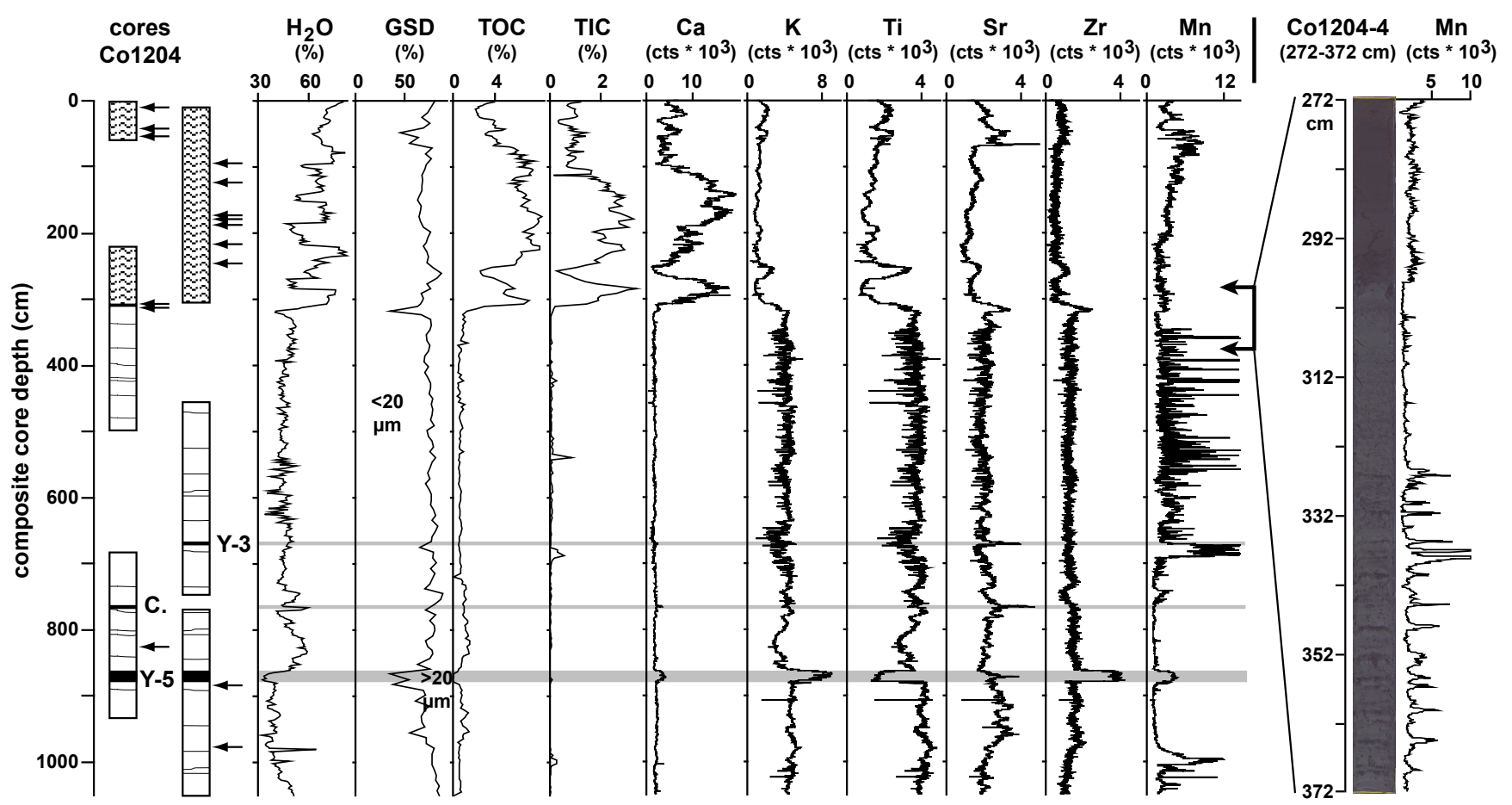

Fig. 2. Lithology, water content, grain-size distribution (GSD), total organic carbon (TOC), total inorganic carbon (TIC), and calcium (Ca), potassium $(\mathrm{K})$, titanium $(\mathrm{Ti})$, strontium $(\mathrm{Sr})$, zirconium $(\mathrm{Zr})$ and manganese $(\mathrm{Mn})$ counts of composite core Co1204 from Lake Prespa. Individual core segments are indicated to the left. Arrows indicate horizons, which were used for radiocarbon dating. Black bars in the lithology mark tephra horizons. The line scan photo to the right is from core segment Co1204-4, 272-372 cm field depth. This segment contains the transition from greyish Pleistocene sedimentation (bottom) to olive to brownish Holocene sedimentation (top). Maxima in Manganese (Mn) counts from XRF scanning in this segment correlate with dark grey spots or horizons and indicate occurrence of concretions.

its position between the Y-5 and the presumed Codola tephra (Fig. 3). Samples KIA36357 and KIA36358 from below the Y-5 tephra have older ages than the Y-5 tephra, but were not taken into consideration for establishing the age-depth model, as they are close to or above the limits of radiocarbon dating (Table 1) and a number of extraordinary stratigraphic inconsistencies in radiocarbon ages in samples from above and below the Y-5 tephra have been reported from other sites (e.g., Fedele et al., 2008).

The upper lithological unit occurs between $314 \mathrm{~cm}$ depth to the core top and is characterized by its distinctive olive to brownish colour (cf. Fig. 2). The absence of lamination throughout this unit indicates bioturbation. The grain-size composition is again dominated by fine-grained material, but ice transported gravel and sand grains were not found. This implies sedimentation under relatively calm conditions, i.e., undisturbed pelagic sedimentation, and moderate or no ice cover during winter. The olive to brownish colour of this unit, the significantly increased TOC and decreased $\mathrm{K}$ and $\mathrm{Ti}$, suggest a distinctly higher proportion of organic matter. This can be explained by increased productivity and/or less decomposition. Both scenarios are supported by a good correspondence between TOC, TIC and Ca. Increased calcite precipitation in the water column (probably due to a higher productivity or less dissolution of precipitated calcite due to less decomposition of organic matter at the sediment surface) occurred during the interglacial in Lake Ohrid (Wagner et al., 2008; Vogel et al., 2010a) and indicates a higher trophic state of the lake. Concretions or concretionary horizons of $\mathrm{Mn}$ compounds, indicating paleo redox fronts in the sediments, are absent throughout the upper lithological unit (Fig. 2). In the study of lake Baldeggersee in Switzerland, the highest Mn concentrations in the sediments were correlated with periods of highest seasonal oxygen variations in the bottom waters (Schaller et al., 1997). The absence of significant Mn peaks in this part of core Co1204 is probably due to bioturbation and/or incomplete mixing of the water column and relatively low oxygen concentrations, these features are characteristic of lakes in mesotrophic or eutrophic states. The radiocarbon ages show that this unit was deposited during the Holocene (Table 1).

Although only three tephras were detected in core Co1204, these tephras can be used as independent tie points to link the sediment records from Lake Prespa with those from Lake Ohrid. The Y-6 tephra, which was observed in the sediment record from Lake Ohrid and was estimated to have an age of $49.2 \pm 1.1 \mathrm{ka}$ (Vogel et al., 2010c; Sulpizio et al., 2010), was not found in core Co1204 from Lake 


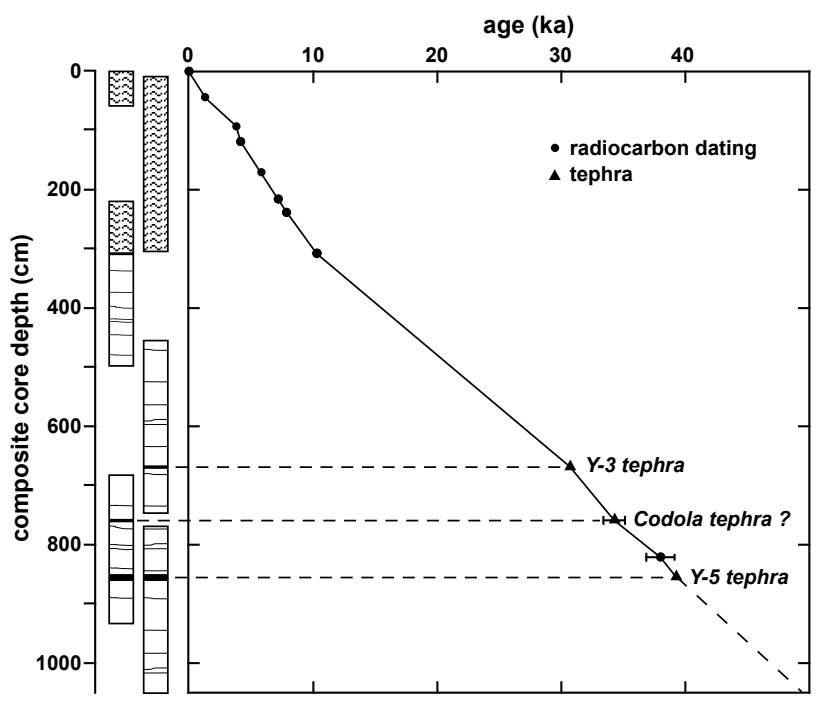

Fig. 3. Age-depth model of core Co1204 based on linear interpolation between dated horizons. The ages from tephras and cryptotephras are indicated by triangles (Sulpizio et al., 2010). The ages from radiocarbon dating of macrofossils are indicated by black dots and were converted in (ka) based on the calibrated ages in Table 1 (factor $10^{3}$ ). Error bars are given for all tephra and radiocarbon ages according to Tables 1 and 2, but are partly overlain by the triangles and dots.

Prespa. Tephra PT0704-3 from 879.3-863.3 cm depth in core Co1204, which corresponds with the Y-5 tephra, can be used as the lowermost tie point dated to $39.3 \pm 0.1$ a (Table 2; ${ }^{40} \mathrm{Ar} /{ }^{39} \mathrm{Ar}$ dating on sanidine crystals; De Vivo et al., 2001). For establishing an age-depth model on core Co1204, the three tephras (Table 2) and radiocarbon ages with a sufficient amount of carbon were used (Table 1). Linear interpolation between the dated horizons reveal no significant changes in the sedimentation rates, except of slightly higher sedimentation rates during the glacial compared with the Holocene period and some minor changes in the latter (Fig. 3). This suggests that the record from Lake Prespa continuously covers the past ca. $48 \mathrm{ka}$. The only indication for a potential gap in the record occurs at the Pleistocene/Holocene transition, where a thin layer of coarse-grained sediments and a sharp change in lithology and other changes in the proxies occur (Fig. 2). However, the absence of shell or macrophyte remains implies that a lake level lowstand or even a complete desiccation can likely be excluded. Moreover, the very shallow bathymetry of the lake argues against significant mass movement processes. Hence, the only reliable explanation for a hiatus and the occurrence of coarse sediments would be that wind-driven currents in Lake Prespa were much stronger or had a different location or extent compared to today and led to erosion of fine-grained sediments. However, to date there is no other evidence for stronger aeolian activity around the Pleistocene/Holocene transition in the region (Vogel et al., 2010a).

\section{Interpretation}

The general sedimentation pattern of Lake Prespa matches well with the sedimentation pattern in Lake Ohrid. Small variations in sediment composition during the glacial period indicate a relatively stable environment in both lakes. The sporadic occurrence of ice transported gravel and sand grains, and the absence or very low TIC and TOC, together characterize glacial sedimentation (Fig. 4). The occurrence of ice transported gravel and sand grains indicates that both lakes had significantly more ice cover during the glacial period than today when the lakes remain mostly ice-free during winter. Cold conditions with a typical steppe biome, also reported from other records in the region (e.g., Allen et al., 2000; Matrat et al., 2004), and ice cover during winter likely led to dimictic conditions in Lake Ohrid during this period (Wagner et al., 2009; Vogel et al., 2010a). Low productivity and bottom water oxygenation twice a year led to low organic matter accumulation and enhanced decomposition of organic matter. Similar conditions and processes apparently prevailed in Lake Prespa, since similar TOC and TIC content (Fig. 4) suggest that this lake was also oligotrophic during the glacial period. However, there is a slight difference between both lakes at the end of Marine Isotope stage (MIS) 3 , between ca. 44 and $32 \mathrm{ka}$. This period is thought to have been slightly warmer (e.g., Geraga et al., 2005) and shows a maximum in arboreal pollen in the Lake Ohrid (Wagner et al., 2009; Fig. 5). At this time both lakes preserved slightly higher amounts of organic matter. As the increase in TOC during this period is higher in Lake Prespa compared to Lake Ohrid (Fig. 4), it is assumed that the slightly warmer conditions shifted the trophic state in Lake Prespa towards more mesotrophic conditions, whilst oligotrophic conditions persisted in Lake Ohrid.

The lowest organic matter and most numerous concretionary horizons (as expressed by high Mn counts; Fig. 5) are found around MIS 2 (between ca. 30 and $12 \mathrm{ka}$ ). The high $\mathrm{Mn}$ content indicates that the seasonal variation in bottom water oxygenation were highest during this period (cf., Schaller et al., 1997). This period corresponds to the Late Weichselian glaciation maximum when local ice caps were widespread and also likely covered the Galiçica mountain range down to ca. $1500 \mathrm{~m}$ a.s.l. (Hughes et al., 2006; Kuhlemann et al., 2008). The core from Lake Prespa does not record evidence of glaciation down to the shore of Lake Prespa, such as proposed by Belmecheri et al. (2009). However, very cold conditions during the Last Glacial Maximum, with temperatures $6-9{ }^{\circ} \mathrm{C}$ lower than today (Peyron et al., 1998; Hayes et al., 2005), are likely correlated with oligotrophic conditions in the lake. This would have reduced supply and replenishment of nutrients and $\mathrm{Ca}^{2+}$ and $\mathrm{HCO}^{3-}$ ions, and fostered decomposition of organic matter and dissolution of calcite by a well oxygenated water column and surface sediment, similar conditions have been reported from Lake Ohrid (Vogel et al., 2010a). 

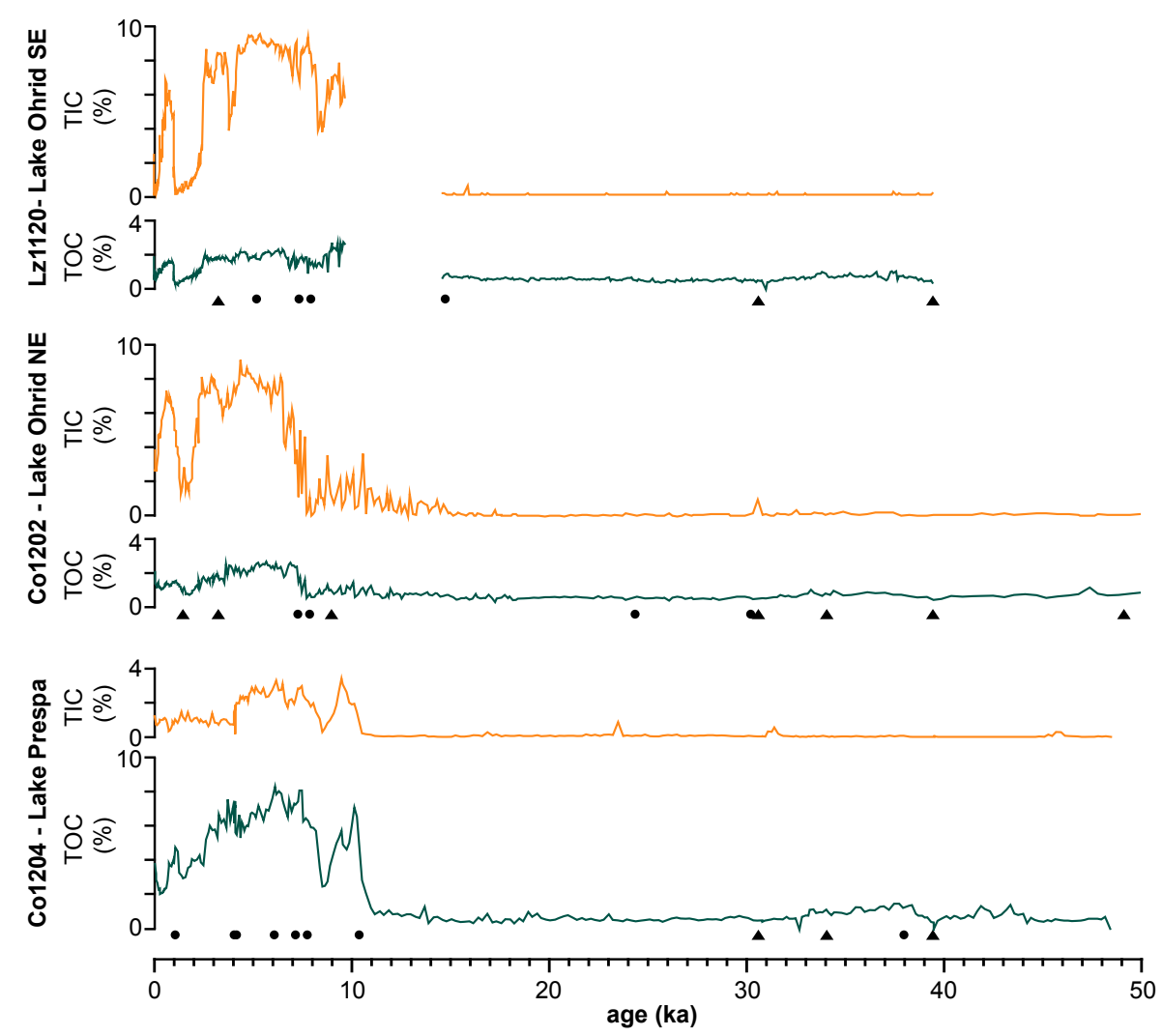

Fig. 4. Comparison of total organic carbon (TOC) and total inorganic carbon (TIC) in cores from Lake Prespa (Co1204) and Lake Ohrid (Co1202 and Lz1120). For location of the cores see Fig. 1. Black dots and triangles in the cores from lakes Prespa and Ohrid indicate horizons, which were used for radiocarbon dating and tephrochronology.

Despite the only marginal variations in long-term sedimentation conditions in both lakes during the Pleistocene, there are some distinct short-term fluctuations. These are best defined by distinct TIC peaks and maxima in Mn concretionary horizons in the Lake Prespa record and by maxima in $\mathrm{Zr} / \mathrm{Ti}$ and sand content in the Lake Ohrid record (Figs. 2 and 5). Although expressed in different proxies, the synchrony of these short-term events in both lakes is assured by the tephra horizons providing a good age control during the last ca. $50 \mathrm{ka}$. Beyond this time, the age control in the Lake Ohrid record is not well constrained (cf. Vogel et al., 2010c) and comparable data from Lake Prespa does not yet exist. As the tephras were subtracted from the records and the events are located above, below or even far away from the respective tephra horizons, it can be excluded that the short-term events were caused by tephra deposition in the lakes or their catchments. Tentatively, the short-term events can be correlated with the Heinrich events H1-H6 as identified from several marine records from the North Atlantic (e.g., Bond et al., 1993; McManus et al., 1999; de Abreu et al., 2003; Fig. 5). It is thought most likely that the Heinrich events in the North Atlantic are correlated with increased mixing in the water column of Lake Prespa, as indicated in
Mn and TIC peaks. Mixing indicates higher aeolian activity in the region, and compares well to the interpretation of the $\mathrm{Zr} / \mathrm{Ti}$ maxima and sand content in Lake Ohrid (Vogel et al., 2010a). Heinrich events are also correlated with relatively cold and dry conditions reported from other Mediterranean records (e.g., Roberts et al., 2008; Wohlfarth et al., 2008; Stein et al., 2009; Castañeda et al., 2010) and inferred from minima in arboreal pollen of Lake Ohrid (cf. Wagner et al., 2009). These conditions could have led to lower lake levels and increased ion concentration in Lake Prespa, thus promoting $\mathrm{MnCO}_{3}$ formation (Schaller et al., 1997). It is difficult, however, to define trends in the variations in strength of the Heinrich events across the Mediterranean region. We would assume that the influence of the Heinrich events on the atmospheric circulation patterns weakens with increasing distance from the North Atlantic. This cannot be observed in the existing records, most likely because the records use different proxies such as vegetation change, lake level change, or sedimentological and geochemical change and these all reflecting different environmental change. Moreover, a regional comparison is hampered by the obvious differences between individual proxies from a single record or from neighbouring records. For example, ice rafted debris (IRD) content and the 


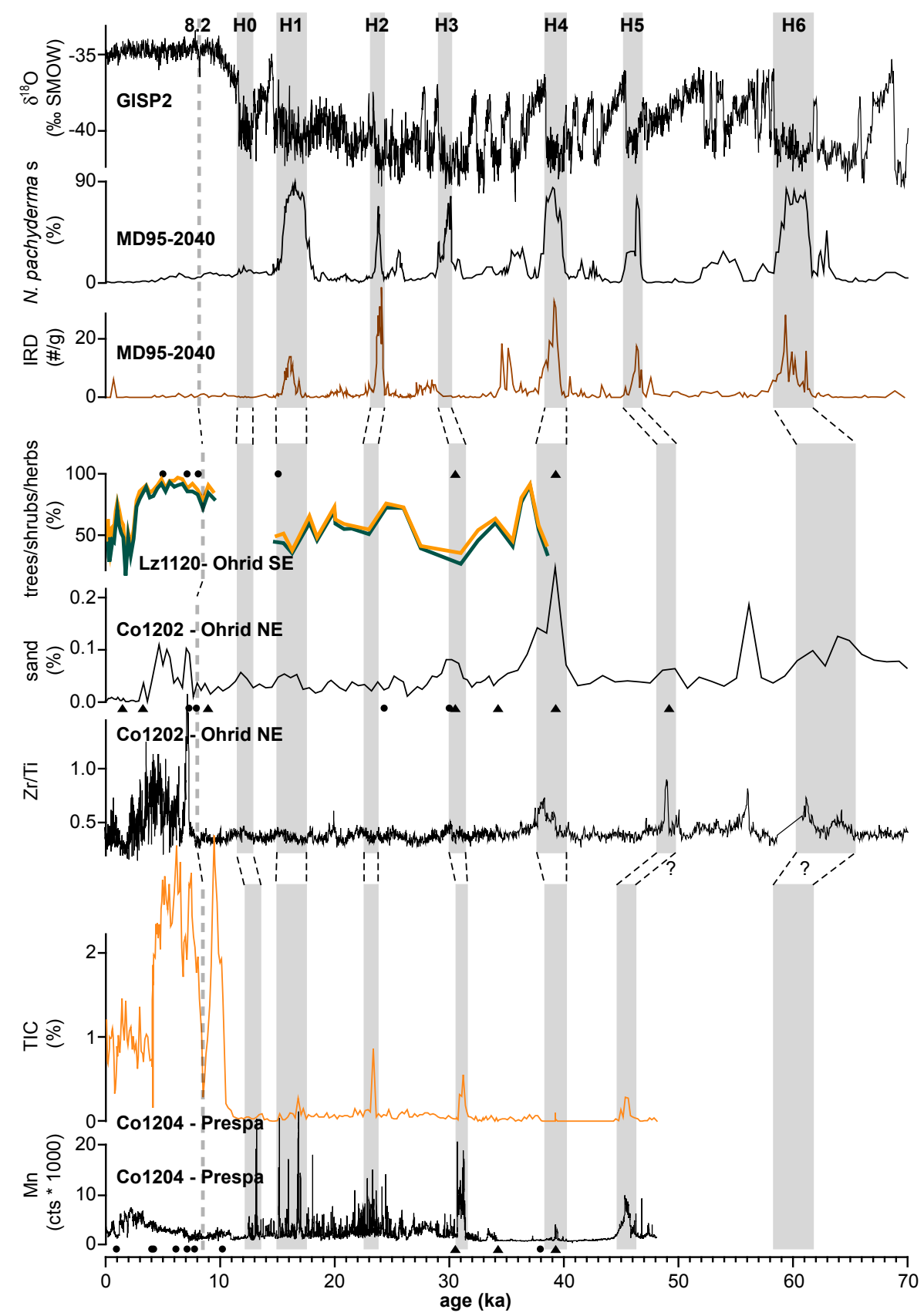

Fig. 5. Palaeoenvironmental records from Lake Prespa (core Co1204) and Lake Ohrid (cores Lz1120 and Co1202; Wagner et al., 2009; Vogel et al., 2010a) compared with the number of IRD grains and the cold water thriving foraminifera $N$. pachyderma from the western Iberian margin (Fig. 1; MD95-2040; de Abreu et al., 2003) and with the $\delta^{18}$ O record from the GISP2 ice core (Grootes et al., 1993). Black dots and triangles in the cores from lakes Prespa and Ohrid indicate horizons, which were used for radiocarbon dating and tephrochronology. The timing and thickness of Heinrich events H1-H6 is according to de Abreu et al. (2003).

occurrence of the cold water thriving foraminifera N. pachyderma in the record from the western Iberian margin do not clearly indicate which Heinrich event was most pronounced (Fig. 5; de Abreu et al., 2003). A similar inconsistent pattern can be observed in the records from lakes Prespa and Ohrid. For example, whilst the sand content in Lake Ohrid indicates highest aeolian activity during $\mathrm{H} 4$, the corresponding Mn and TIC peaks in Lake Prespa are relatively small (Fig. 5). This discrepancy can partly be explained by interferences when subtracting the environmental signals of Y-5 tephra from the respective records, as there is an overlap between the $\mathrm{H} 4$ event and the Campanian Ignimbrite eruption 
(Fedele et al., 2008). However, it also might be that the individual proxies indicate slightly different reactions of the lakes to changes in environmental conditions.

The Pleistocene/Holocene transition is relatively sharp in Lake Prespa and apparently more pronounced than in Lake Ohrid (Fig. 5). Although a gap in the record from Lake Prespa cannot be completely excluded, the sharp transition could also be caused by a delay of full interglacial conditions compared to other palaeoclimate reconstructions (Allen et al., 1999; Martrat et al., 2004; Lawson et al., 2004; Kotthoff et al., 2008; Bordon et al., 2009). Such a delay has already been suggested in Lake Ohrid and attributed to prevailing cold winters with at least partial ice cover in the early Holocene (Vogel et al., 2010a). Similar conditions might have also affected Lake Prespa.

After the establishment of full interglacial Holocene conditions, absence of ice transported gravel and sand grains and high amounts of TIC and TOC (albeit with some significant fluctuations) characterize the sedimentation in both lakes (Fig. 4). The pollen assemblages from Lake Ohrid are dominated by arboreal pollen and indicate that forests were widespread in the catchment during the first half of the Holocene (Wagner et al., 2008; Fig. 5). However, increased $\mathrm{Zr} / \mathrm{Ti}$ ratios and relatively high sand content in the record from Lake Ohrid indicate relatively high aeolian activity. Increased runoff from the catchment can likely be excluded, because the highest $\mathrm{Zr} / \mathrm{Ti}$ and high sand contents occur when the climate became drier around $7.5 \mathrm{ka}$ (Vogel et al., 2010a). Lake level fluctuations could also have occurred, but should be of minor importance in the deep Lake Ohrid and cannot be reconstructed from our data in the relatively shallow Lake Prespa. Although the sedimentation pattern in both lakes is similar during the Holocene, organic matter content is much higher and carbonate content is much lower in Lake Prespa compared to Lake Ohrid (Fig. 4). These differences are most likely due to the differences in the catchment and the hydrology of both lakes (cf. Leng et al., 2010). Whilst Lake Ohrid is mainly fed by water from karst aquifers (Matzinger et al., 2006b), which provides sufficient $\mathrm{Ca}^{2+}$ ions to the lake, Lake Prespa is mainly fed by river runoff from numerous small streams (Matzinger et al., 2006a) from the granitoid and $\mathrm{Ca}^{2+}$ ion depleted eastern part of the catchment. The overall higher organic matter content in Lake Prespa compared to Lake Ohrid is likely the result of the lower water depths of Lake Prespa, thus leading to higher water temperatures and enhanced productivity in summer. In addition, these conditions likely promoted oxygen depletion of the bottom waters during summer, and could have led to decreased decomposition of organic matter. This is supported by the absence of Mn concretionary horizons, which suggest restricted bottom water oxygenation. At present, the prevalence of anoxic bottom water conditions during the summer in Lake Prespa is indicated by intense release of methane bubbles from the entire lake bed. The distinct decline in TIC in Lake Prespa at $4 \mathrm{ka}$ could be caused by a significant increase in lake level, as is reported from Lake Maliq nearby (Fouache et al., 2010). However, this is in conflict with increasing aridification inferred from stable isotope studies from lakes Prespa and Ohrid (Leng et al., 2010) and also reported from several other studies (e.g., Roberts et al., 2008) around this period. The mid to late Holocene climatic and hydrological history in the northern Mediterranean apparently is characterized by increasing anthropogenic influence, forest clearance, and/or tectonic activity probably led to local particularities. The mid Holocene shift in environmental conditions seems to be less pronounced in the sediment sequences from Lake Ohrid (Fig. 4), probably because the concentration of $\mathrm{Ca}^{2+}$ ions in the water of Lake Ohrid was less affected due to the larger volume of this lake and the ongoing ion supply from karst aquifers. The sharp decrease in carbonate content in Lake Ohrid at about $2.5 \mathrm{ka}$, when anthropogenic influence led to a decrease in arboreal pollen and probably to increased erosion in the catchment of Lake Ohrid (Wagner et al., 2009), corresponds well with a decrease in organic matter in Lake Prespa (Fig. 4). A similar correspondence can be observed during the following period and suggests similar environmental and anthropogenic impacts on both lakes, which are however expressed in different parameters.

Short-term events during the Holocene, such as the $8.2 \mathrm{ka}$ event or the $4.2 \mathrm{ka}$ event, are recorded in lakes Prespa and Ohrid by a distinct decrease of carbonate and organic matter (cf. Wagner et al., 2009). However, the records from lakes Prespa and Ohrid reveal distinct differences in the reaction of both lakes to cooler or drier conditions. The most sensitive reaction to the $8.2 \mathrm{ka}$ event appears from Lake Prespa, where carbonate and organic matter content show a distinct minimum. In Lake Ohrid, only the carbonate content in core Lz1120 from the southeastern part of the lake shows a distinct minimum (Fig. 5). In core Co1202 from the northeastern part of the lake, this minimum is less pronounced, probably because there is less influence of karstic springs. The organic matter content in Lake Ohrid, which in general is low due to its oligotrophic state, is barely affected by the cooling event. The distinct minimum of carbonate and organic matter content in Lake Prespa and the distinct minimum of carbonate in core Lz1120 suggest that the $8.2 \mathrm{ka}$ event in the Balkan region was correlated to cooler and drier conditions. This is supported by biomarker measurements around the $8.2 \mathrm{ka}$ cooling event, which suggest that at this time the region around Lake Ohrid was relatively dry (Holtvoeth et al., 2010). The $4.2 \mathrm{ka}$ event is different, as organic matter content remains relatively stable in both lakes. The distinct carbonate minimum in core Lz1120 implies that this event can be correlated with a distinct decrease of the karstic inflow and drier conditions rather than a period of cooler conditions. A short period of drier conditions is in conflict with a reconstructed lake level highstand in Lake Maliq nearby (Fouache et al., 2010), but is also indicated in several other climate records from the Mediterranean region (Magny et al., 2009). 


\section{Conclusions}

The study of a sediment record from Lake Prespa and the comparison of the results with those derived from former studies of Lake Ohrid reveal similar sedimentation patterns in both lakes during the last ca. $48 \mathrm{ka}$. The occurrence of tephra layers in both lakes and radiocarbon dates provide reliable chronological constraints for the sediment successions.

During the last ca. $48 \mathrm{ka}$, there is no indication for distinctly lower lake levels of Lake Prespa compared to today, although the relatively low volume and low water depth make the lake very sensitive to changes in precipitation and evaporation. We cannot exclude that the level of Lake Prespa was much higher in the past and that the recent level is close to its minimum.

The Pleistocene records from lakes Prespa and Ohrid indicate relatively stable sedimentation conditions. At least partial ice-cover on the lakes during winter, a well-mixed water column and oligotrophic conditions with a marginal increase of lake productivity at the end of MIS 3 characterize the lakes. Coldest conditions during MIS 2 are documented by the lowest organic matter content in both lakes and the highest abundance of concretionary horizons in Prespa, thus indicating a well mixed water column.

The Pleistocene/Holocene transition in both lakes is relatively sharp and delayed compared to other climate records from the region. The Holocene sediments are characterized by high organic matter, particularly in Lake Prespa, and high carbonate, particularly in Lake Ohrid. The differences between both lakes indicate that Lake Prespa was under mesotrophic conditions during this period, since the lake water warms up faster in spring and summer. Lake Ohrid in contrast, with a larger volume and water depth, remained oligotrophic during the Holocene.

Short-term events are well documented during the Pleistocene and the Holocene. The most prominent short-term events during the Pleistocene are tentatively correlated with the Heinrich events, which are characterized by increased aeolian activity, lower temperatures and/or increased aridity in the Balkan region. During the Holocene, the $8.2 \mathrm{ka}$ event and the $4.2 \mathrm{ka}$ event are well recorded in both lakes, but indicate different environmental change, with cool and dry conditions characterizing the 8.2 event and rather dry conditions characterizing the $4.2 \mathrm{ka}$ event. Anthropogenic impact is superimposed on the climatic and environmental change during the past ca. $2500 \mathrm{yr}$ BP.
Acknowledgements. The study was partly funded by the German Research Foundation (Wa2109/1 and CRC806). The INGV-DPC project is thanked for the study of tephra layers. Ariane Liermann, Jens Aubel, and Michael Fritz contributed significantly to successful fieldwork. The fieldwork benefitted also from great logistic support by the Hydrobiological Institute, Ohrid, and particularly by Goce Kostoski, Sasho Trajanovski, and Zoran Brdarovski. Special thanks are due to Robert from the police department in Stenje, Melanie Leng for improvement of the English, and Julie Brigham-Grette and an anonymous reviewer for suggestions and comments on the manuscript.

Edited by: V. Brovkin

\section{References}

Albrecht, C. and Wilke, T.: Ancient Lake Ohrid: biodiversity and evolution, Hydrobiol., 615, 103-140, 2008.

Allen, J. R. M., Brandt, U., Brauer, A., Hubberten, H.-W., Huntley, B., Keller, J., Kraml, M., Mackensen, A., Mingram, J., Negendank, J. F. W., Nowaczyk, N. R., Oberhänsli, H., Watts, W. A., Wulf, S., and Zolitschka, B.: Rapid environmental changes in southern Europe during the last glacial period, Nature, 400, 740743, 1999.

Allen, J. R. M., Watts, W. A., and Huntley, B.: Weichselian palynostratigraphy, palaeovegetation and palaeoenvironment; the record form Lago Grande di Monticchio, southern Italy, Quat. Intern., 73/74, 91-110, 2000.

Anovski, T., Naumovski, J., Kacurkov, D., and Kirkov, P.: A study of the origin of waters of St. Naum Springs, Lake Ohrid, Fisika, 12, 76-86, 1980 (in Macedonian).

Belmecheri, S., Namiotko, T., Robert, C., von Grafenstein, U., and Danielopol, D. L.: Climate controlled ostracod preservation in Lake Ohrid (Albania, Macedonia), Palaeogeogr. Palaeoclimatol. Palaeoecol., 277, 236-245, 2009.

Bond, G., Broecker, W., Johnsen, S., McManus, J., Labeyrie, L., Jouzel, J., and Bonani, G.: Correlations between climate records from the Atlantic sediments and Greenland ice, Nature, 365, 143-147, 1993.

Bordon, A., Peyron, O., Lézine, A.-M., Brewer, S., and Fouache, E.: Pollen-inferred Late-Glacial and Holocene climate in southern Balkans (Lake Maliq), Quat. Intern., 200, 19-30, 2009.

Castañeda, I. S., Schefuß, E., Pätzold, J., Sinninghe Damsté, J. S., Weldeab, S., Schouten, S.: Millenial-scale sea surface temperature changes in the eastern Mediterranean (Nile River Delta region) over the last 27,000 years, Palaeoceanography, 25, PA1208, doi:10.1029/2009PA001740, 2010.

Danzeglocke, U., Jöris, O., and Weninger, B.: CalPal-2007 online, http://www.calpal-online.de/, last access: 21 November 2009.

de Abreu, L., Shackleton, N. J., Schönfeld, J., Hall, M. A., and Chapman, M. R.: Millenial-scale oceanic climate variability off the Western Iberian margin during the last two glacial periods, Mar. Geol., 196, 1-20, 2003.

de Vivo, B., Rolandi, G., Gans, P. B., Calvert, A., Bohrson, W. A., Spera, F. J., and Belkin, H. E.: New constraints on the pyroclastic eruptive history of the Campanian volcanic Plain (Italy), Mineral. Petrol., 73, 47-65, 2001. 
Eftimi, R. and Zoto, J.: Isotope study of the connection of Ohrid and Prespa lakes, in: Proceedings of International Symposium towards Integrated Conservation and Sustainable Development of Transboundary Macro and Micro Prespa Lakes, PPNEA, ILAR Typography, Tirana, Albania, 32-37, 1997.

Fedele, F. G., Giacco, B., and Hajdas, I.: Timescales and cultural process at $40,000 \mathrm{BP}$ in the light of the Campanian Ignimbrite eruption, Western Eurasia, J. Human Evol., 55, 834-857, 2008.

Fouache, E., Desrulles, S., Magny, M., Bordon, A., Oberweiler, C., Coussot, C., Touchais, G., Lera, P., Lézine, A.-M., Fadin, L., and Roger, R.: Palaeogeographical reconstructions of Lake Maliq (Korça Basin, Albania) between 14,000 BP and 2000 BP, J. Archeol. Sci., 37, 525-535, 2010.

Geraga, M., Tsaila-Monopolis, S., Ioaim, C., Papatheodorou, G., and Ferentinos, G. Short-term climate changes in the southern Aegean Sea over the last 48,000 years, Palaeogeogr. Palaeoclimatol. Palaeoecol., 220, 311-332, 2005.

Granina, L., Müller, B., and Wehrli, B.: Origin and dynamics of Fe and Mn sedimentary layers in Lake Baikal, Chem. Geol. 205, 55-72, 2004.

Grootes, P. M., Stuiver, M., White, J. W. C., Johnsen, S. J., and Jouzel, J.: Comparison of oxygen isotope records from the GISP2 and GRIP Greenland ice cores, Nature, 366, 552-554, 1993.

Hadzisce, S. D.: Das Mixophänomen im Ohridsee im Laufe der Jahre 1941/42-1964/65, Verh. Int. Verein. Limnol., 16, 134-138, 1966.

Hayes, A., Kucera, M., Kallel, N., Sbaffi, L., and Rohling, E. J.: Glacial Mediterranean sea surface temperatures based on planktonic foraminiferal assemblages, Quat. Sci. Rev., 24, 999-1016, 2005.

Holtvoeth, J., Vogel, H., Wagner, B., and Wolff, G. A.: Lipid biomarkers in Holocene and glacial sediments from ancient Lake Ohrid (Macedonia, Albania), Biogeosciences Discuss., 7, 46074640, doi:10.5194/bgd-7-4607-2010, 2010.

Hughes, P., Woodward, J., and Gibbard, P.: Quaternary glacial history of the Mediterranean mountains, Progr. Phys. Geogr., 30, 334, 2006.

Kotthoff, U., Müller, U. C., Pross, J., Schmiedl, G., Lawson, I. T., van de Schootbrugge, B., and Schulz, H.: Lateglacial and Holocene vegetation dynamics in the Aegean region: an integrated view based on pollen data from marine and terrestrial archives, The Holocene, 18, 1019-1032, 2008.

Kuhlemann, J., Rohling, E. J., Krumrei, I., Kubik, P., Ivy-Ochs, S., and Kucera, M.: Regional synthesis of Mediterranean atmospheric circulation during the last Last Glacial Maximum, Science, 321, 1338-1340, 2008.

Lawson, I. T., Frogley, M., Bryant, C., Preece, R., and Tzedakis, P.: The Lateglacial and Holocene environmental history of the Ioannina basin, north-west Greece, Quat. Sci. Rev., 23, 15991625, 2004.

Leng, M. J., Baneschi, I., Zanchetta, G., Jex, C. N., Wagner, B., and Vogel, H.: Late Quaternary palaeoenvironmental reconstruction from Lakes Ohrid and Prespa (Macedonia/Albania border) using stable isotopes, Biogeosciences, 7, 3109-3122, doi:10.5194/bg7-3109-2010, 2010.

Lézine, A.-M., von Grafenstein, U., Andersen, N., Belmecheri, S., Bordon, A., Caron, B., Cazet, J. P., Erlenkeuser, H., Fouache, E., Grenier, C., Huntsman-Mapila, P., Hureau-Mazaudier, D.,
Manelli, D., Mazaud, A., Robert, C., Sulpizio, R., Tiercelin, J. J., Zanchetta, G., and Zeqollari, Z.: Lake Ohrid, Albania, provides an exceptional multi-proxy record of environmental changes during the last glacial-interglacial cycle, Palaeogeogr. Palaeoclimatol. Palaeoecol., 287, 116-127, 2010.

Magny, M., Vanniere, B., Zanchetta, G., Fouache, E., Touchais G., Petrika, L., Coussot, C., Walter-Simonnet, A.-V., and Arnaud, F.: Possible complexity of the climatic event around 4300-3800 cal. BP in the central and western Mediterranean, The Holocene, 19, 823-833, 2009.

Martrat, B., Grimalt, J. O., Lopez-Martinez, C., Cacho, I., Sierro, F. J., Flores, J. A., Zahn, R., Canals, M., Curtis, J. H., and Hodell, D. A.: Abrupt temperature changes in the Western Mediterranean over the past 250,000 years, Science, 306, 1762-1765, 2004.

Matzinger, A., Jordanoski, M., Veljanoska-Sarafiloska, E., Sturm, M., Müller, B., and Wüest, A.: Is Lake Prespa jeopardizing the ecosystem of ancient Lake Ohrid?, Hydrobiol., 553, 89-109, 2006a.

Matzinger, A., Spirkovski, Z., Patceva, S., and Wüest, A.: Sensitivity of ancient Lake Ohrid to local anthropogenic impacts and global warming, J. Great Lakes Res., 32, 158-179, 2006 b.

Matzinger, A., Schmid, M., Veljanoska-Sarafiloska, E., Patceva, S., Guseska, D., Wagner, B., Müller, B., Sturm, M., and Wüest, A.: Eutrophication of ancient Lake Ohrid: global warming amplifies detrimental effects of increased nutrient inputs, Limnol. Oceanogr., 52, 338-353, 2007.

McManus, J. F., Oppo, D. W., and Cullen, J. L.: A 0.5-MillionYear Record of Millennial-Scale Climate Variability in the North Atlantic, Science, 283, 971-975, 1999.

Meybeck, M.: Global distribution of lakes, in: Physics and Chemistry of Lakes, edited by: Lerman, A., Imboden, D., and Gat, J., Springer, Berlin, 1-32, 1995.

Peyron, O., Guiot, J., Cheddadi, R., Tarasov, P., Reille, M., de Beaulieu, J.-L., Bottema, S., and Andrieu, V.: Climatic reconstruction in Europe for 18,000 yr. B.P. from pollen data, Quat. Res., 49, 183-196, 1998.

Popovska, C. and Bonacci, O.: Basic data on the hydrology of Lakes Ohrid and Prespa, Hydrol. Proc., 21, 658-664, 2007.

Roberts, N., Jones, M. D., Benkaddour, A., Eastwood, W. J., Filippi, M. L., Frogley, M. R., Lamb, H. F., Leng, M. J., Reed, J. M., Stein, M., Stevens, L., Valero-Garcés, B., and Zanchetta, G.: Stable Isotope records of Late Quaternary climate and hydrology from Mediterranean lakes: the ISOMED synthesis, Quat. Sci. Rev., 27, 2426-2441, 2008.

Roelofs, A. K. and Kilham, P.: The diatom stratigraphy and paleoecology of Lake Ohrid, Yugoslavia, Palaeogeogr. Palaeoclimatol. Palaeoecol., 42, 225-245, 1983.

Salemaa, H.: Lake Ohrid, in: Speciation in ancient lakes, edited by: Martens, K., Goddeeris, B., and Coulter, G., Arch. Hydrobiol., 44, 55-64, 1994.

Schaller, T., Moor, H. C., and Wehrli, B.: Sedimentary profiles of $\mathrm{Fe}, \mathrm{Mn}, \mathrm{V}, \mathrm{Cr}$, As and Mo as indicators of benthic redox conditions in Baldeggersee, Aquat. Sci., 59, 345-361, 1997.

Stankovic, S.: The Balkan Lake Ohrid and its living world, Monographiae Biologicae IX, edited by: Bodenheimer, F. S. and Weisbach, W. W., Dr. W. Junk, Den Haag, The Netherlands, 1960.

Stein, M., Torfstein, A., Gavrieli, I., and Yechieli, Y.: Abrupt aridities and salt deposition in the post-glacial Dead Sea and their North Atlantic Connection, Quat. Sci. Rev., 29, 567-575, 2009. 
Sulpizio, R., Zanchetta, G., D’Orazio, M., Vogel, H., and Wagner, B.: Tephrostratigraphy and tephrochronology of lakes Ohrid and Prespa, Balkans, Biogeosciences Discuss., 7, 3931-3967, doi:10.5194/bgd-7-3931-2010, 2010.

Vogel, H., Wagner, B., Zanchetta, G., Sulpizio, R., and Rosén, P.: A paleoclimate record with tephrochronological age control fort he last glacial-interglacial cycle from Lake Ohrid, Albania and Macedonia, J. Paleolimnol., 44, 295-310, 2010a.

Vogel, H., Wessels, M., Albrecht, C., Stich, H.-B., and Wagner, B.: Spatial variability of recent sedimentation in Lake Ohrid (Albania/Macedonia) - a complex interplay of natural and anthropogenic factors and their possible impact on biodiversity patterns, Biogeosciences Discuss., 7, 3911-3930, doi:10.5194/bgd7-3911-2010, 2010b.

Vogel, H., Zanchetta, G., Sulpizio, R., Wagner, B., and Nowaczyk, N.: A tephrostratigraphic record for the last glacial interglacial cycle from Lake Ohrid, Albania and Macedonia, J. Quat. Sci., 25, 320-338, 2010c.

Wagner, B., Lotter, A. F., Nowaczyk, N., Reed, J. M., Schwalb, A., Sulpizio, R., Valsecchi, V., Wessels, M., and Zanchetta, G.: A 40,000-year record of environmental change from ancient Lake Ohrid (Albania and Macedonia), J. Paleolimnol., 41, 407-430, 2009.
Wagner, B., Sulpizio, R., Zanchetta, G., Wulf, S., Wessels, M., and Daut, G.: The last 40 ka tephrostratigraphic record of Lake Ohrid, Albania and Macedonia: a very distal archive for ash dispersal from Italian volcanoes, J. Volcanol. Geotherm. Res., 177, 71-80, 2008.

Wilke, T., Schultheiß, R., Albrecht, C., Bornmann, N., Trajanovski, S., and Kevrekidis, T.: Native Dreissena freshwater mussels in the Balkans: in and out of ancient lakes, Biogeosciences, 7, 3051-3065, doi:10.5194/bg-7-3051-2010, 2010.

Wohlfarth, B., Veres, D., Ampel, L., Lacourse, T., Blaauw, M., Preusser, F., Andrieu-Ponel, V., Kéravis, D., Lallier-Vergès, E., Björk, S., Davies, S. M., de Beaulieu, J.-L., Risberg, J., Hormes, A., Kasper, H. U., Possnert, G., Reille, M., Thouveny, N., and Zander, A.: Rapid ecosystem response to abrupt climate changes during the last glacial period in western Europe, 40-16 ka, Geology, 36, 407-410, 2008. 